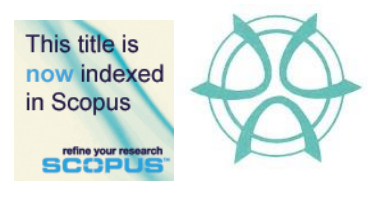

PLANNING MALAYSIA:

Journal of the Malaysian Institute of Planners

SPECIAL ISSUE V (2016), Page 101 - 114

\title{
CAMPUS WALKABILITY IN MALAYSIAN PUBLIC UNIVERSITIES: A CASE-STUDY OF UNIVERSITI MALAYA
}

\author{
Liow Ken Keat ${ }^{1}$, Naziaty Mohd Yaacob ${ }^{2}$ \& Nor Rasidah Hashim ${ }^{3}$ \\ ${ }^{1,2,3}$ Centre for Sustainable Urban Planning \& Real Estate \\ Faculty of Built Environment \\ UNIVERSITY OF MALAYA
}

\begin{abstract}
Universities are important innovation hubs for sustainable development. As universities worldwide are striving to provide conducive living and learning environments for their students and staff, the mobility of campus users is one of the challenges that have to be overcome immediately. In order to understand the issues of campus mobility, this study was conducted to evaluate a component of mobility, i.e. its walkability features and potential. The location of this study was in Universiti Malaya. We divided the study in two stages: 1 . Students' surveys to find out their perceptions on the features, potential and policy on walkability. 2. Direct observations and measurements of the existing walkability conditions (vehicular and pedestrian circulation and the street elements that constitute a walkable environment). The main findings were as follows: Most students perceived the overall walkability environment at UM did not give them a positive walking experience on campus. Street elements that are user-friendly were found to be lacking although there existed some positive ones, e.g. traffic calming devices especially at pedestrian crossing area. Although this is a case study of $\mathrm{UM}$, we feel that the issues are of general interest to other university campuses, especially those located in major cities and having the same organizational structure. We would therefore recommend university management to conduct periodical campus walkability evaluation and to take the user's perceptions seriously so as to provide better adaptation solutions to their campus sustainability projects.
\end{abstract}

Keyword: Walkability, pedestrian-friendly, campus planning 
Liow Ken Keat, Naziaty Mohd Yaacob \& Nor Rasidah Hashim

Campus Walkability in Malaysian Public Universities: A Case-Study of University of Malaya

\section{INTRODUCTION}

Universities worldwide are pledging to provide conducive living and learning environments for their students and staff, and so the mobility of campus users is a challenge that many large universities must address as part of their sustainable campus initiatives. Campus walkability is an important component of campus mobility because these users need to have access to a network of connected, direct and easy to follow routes, linking the hostel, faculties, green spaces, public transport stops and other facilities that will enhance their campus experience, which is based on safety, functionality, pleasure and learning (Banning, 1993; Strange \& Banning, 2001; Makki et al., 2012).

Walking is commonly associated with many benefits, ranging from reducing air pollution, traffic congestion, solving obesity and other health problems encouraging neighbourly interactions and making the urban environment a more enjoyable and safer place to live (Emery \& Crump, 2003). There is sufficient evidence on the link between built environment and walking (Handy, 2005). University administrators including the campus planners must therefore continually monitor the built environment attributes that make up a pedestrian-friendly environment, as well as taking into account the campus community's opinions on how to improve walkability on campus.

The main goal when measuring walkability on a university campus is to advance healthy living, lower emissions and improve sustainable transportation (Angelidis et al., 2014). Walkability is a key component in a sustainable transportation network, and provides social benefits as well as benefits to human health, economic stability, and environmental protection (Lewis, 2004; Park, 2008).

In order to understand the level of campus walkability and its relationship with the environment, we have conducted this study in Universiti Malaya, as a case study of a large, well-established Malaysian public university. Universiti Malaya has embarked on creating a better walking environment by constructing better pathways in certain parts of the campus, e.g. the paths around the lake and the area near the main administrative buildings, however, walking paths at many faculties seem to be lacking in proper upgrading and maintenance work (authors' observation). Our basic assumption is that Malaysian public universities have financial, policy or planning constraints that might slow down or hinder the implementation of a walkable campus concept, therefore this study will hopefully reveal some of the problems.

\section{MATERIALS AND METHODS}

\section{Study Location}

Established in 1962 and built in its present location in Kuala Lumpur, Universiti Malaya (UM) is the oldest public university in Malaysia. As a public university, 
PLANNING MALAYSIA

Sustainable Urban Development

UM's annual student enrolment is high, situated on a vast campus (309 ha) and its management structure is typical of a large organization, as well as its unique location in the middle of Kuala Lumpur city. There are 12 residential colleges and more than 10 learning centres in the university (Figure 1). In 2014, the number of first year students enrolling at UM was 2895, and these students were given residential accommodation in their respective colleges based on their chosen programmes of study (Registration Admissions and Records Section of Universiti Malaya, 2014). The university campus is accessible to the public on most days as the KL, PJ and Damansara gates are opened during the day. Besides the university buses that ferry students and staff around the campus, the RapidBus (public transportation) services along the main road (around the lake) by entering/exiting the KL gate to the nearby Universiti LRT station.

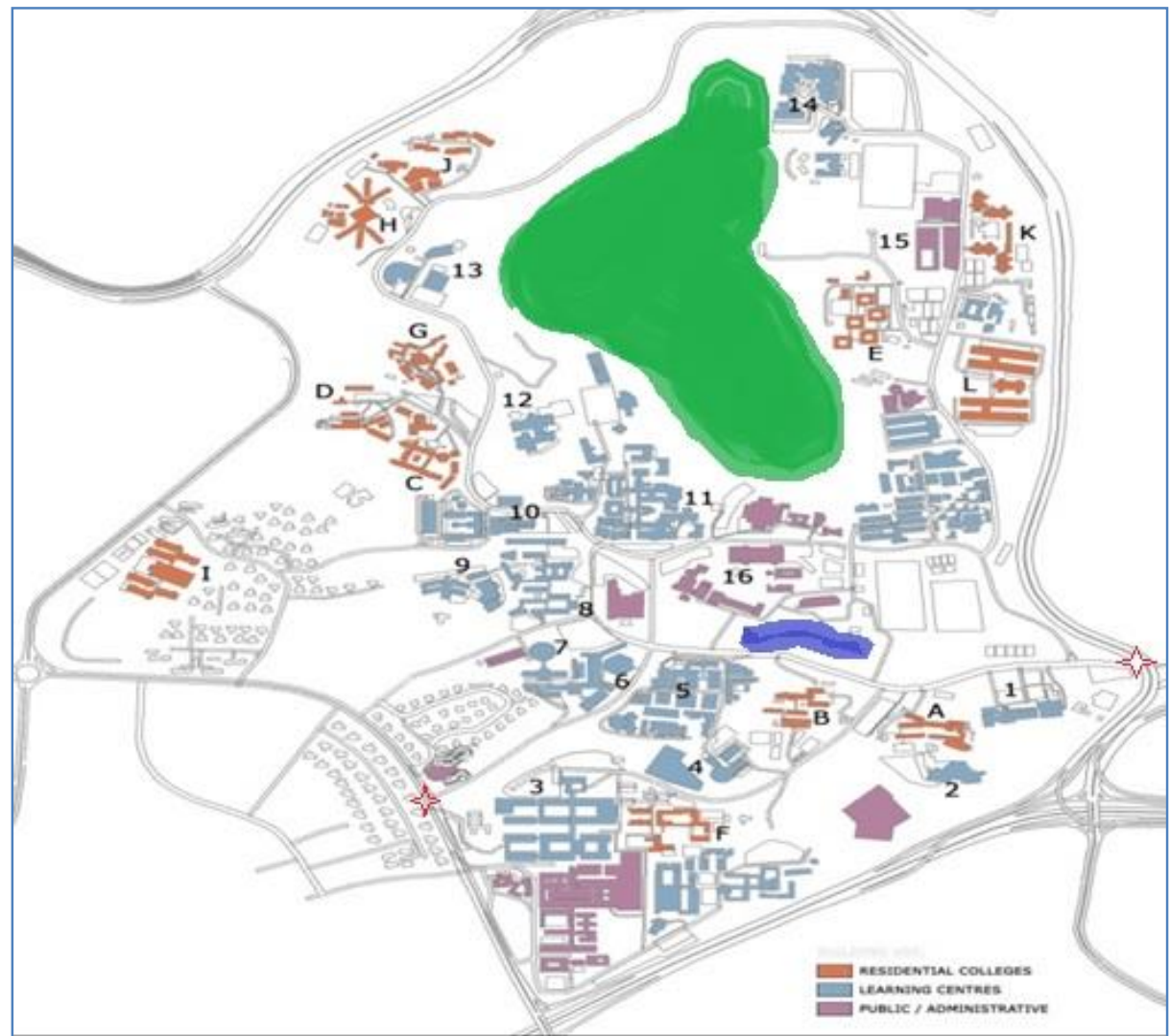

Figure 1: Map of Universiti Malaya campus showing the locations of residential colleges, learning centres (faculties / academies) and administrative buildings. Special features shown are; PJ and KL gates (star), lake (blue) and forested hilly area (green). Source: Universiti Malaya 
Liow Ken Keat, Naziaty Mohd Yaacob \& Nor Rasidah Hashim

Campus Walkability in Malaysian Public Universities: A Case-Study of University of Malaya

The data for this study was collected using two methods, as described below.

1. Opinion survey of students living on campus. A total of 224 First Year students living in eleven residential colleges participated in this survey, which was conducted from 27 October 2014 until 12 November 2014. The participants in the survey were asked closed- and open-ended questions regarding the following topics:

i. Five walkability indicators (Sidewalk width, Sidewalk Maintenance, Streetscape, Shading Devices, Vehicle-emitted pollution).

ii. Walking experience from their colleges to the faculties based on a scale of 1 (best) to 5 (worst) in five different aspects: safety, security, comfort, convenience, and interestingness.

iii. Their opinion on the University No-Car policy of prohibiting first year students to drive cars on campus. This policy was implemented in 2009 in order to promote a green campus.

2. Ground truthing of street elements. During our field work, we used the direct observation technique of measuring and recording the presence (or quantity) or lack of; and evaluated the conditions of the street elements that are important indicators of campus walkability. The direct observation and measurement technique follows the Malaysian Standard of MS 1184:2014 (Malaysian Standards, 2014). The existing conditions were also compared with best practices elsewhere for suggestions on improvement.

\section{RESULTS AND DISCUSSION}

\section{Opinion survey of students living on campus}

The questionnaire survey of students living on campus yielded the following findings. Firstly, based on a list of five walkability indicators, most respondents perceived the overall walkability environment in Universiti Malaya as being constituted of poor features and conditions (Table 1). Sidewalks, which are important walkability features, were not wide enough to allow for comfortable walking especially when one needs to pass each other and/or overtake another pedestrian. The lack of shaded areas along most of the sidewalks might have contributed to the streetscape being dull as well. The noise and fumes emitted by vehicles moving very close to the pedestrians would further negatively affect the walkability experience. 
PLANNING MALAYSIA

Sustainable Urban Development

Table 1: Participants responses towards five walkability indicators.

\begin{tabular}{|c|c|c|c|}
\hline i. & Sidewalk width & $\frac{\text { Sufficient }}{59 \text { students }}(26 \%)$ & $\frac{\text { Insufficient }}{165 \text { students }(74 \%)}$ \\
\hline ii. & Sidewalk Maintenance & $\frac{\text { Well-maintained }}{42(19 \%)}$ & $\frac{\text { Less-maintained }}{182(81 \%)}$ \\
\hline iii. & Streetscape & $\frac{\text { Interesting }}{64(29 \%)}$ & $\frac{\text { Dull }}{160}(71 \%)$ \\
\hline iv. & Shading Devices & $\frac{\text { Provided }}{29(13 \%)}$ & $\frac{\text { None }}{195(87 \%)}$ \\
\hline v. & Noises, Fumes, Vibrations & $\frac{\text { No }}{58}(26 \%)$ & $\frac{\text { Yes }}{166}(74 \%)$ \\
\hline
\end{tabular}

Secondly, when considering the factors of safety, security, comfort, convenience and interestingness, the students gave poor ratings as evidenced by the low total scores of 794 and above being far from the best score of 224 (Table 2).

Table 2: Total rating of five walkability aspects by 224 respondents

\begin{tabular}{lc}
\hline & Total Rating \\
& $(\mathbf{2 2 4}=\mathbf{B e s t} ; \mathbf{6 7 2}=\mathbf{M o d e r a t e ; ~ 1 1 2 0 = W o r s t )}$ \\
\hline Safety & 838 \\
Security & 794 \\
Comfort & 897 \\
Convenience & 820 \\
Interestingness & 923 \\
\hline
\end{tabular}

(all five aspects received poor total rating). The rating for a respondent's walking experience is scored on a 1-5 scale (1 being best; 5 worst); all 224 respondents' scores for each walkability aspect were then pooled to obtain its total score.

Several examples of the students' expressed opinions on such poor walking experience are shared here. Student A cited long distance from the residential college to and from the faculty as being the primary hindrance of walking. On top of that, the poor bus transportation made using a private vehicle seemed a convenient alternative. The two negative aspects of distance and public transportation are indicative of the wider problem of planning, management and even finance. The problem of bus transportation in UM has been mentioned in other studies as well (Mohd Zulhanif et al., 2011; Rugayah et al., 2013). This also leads to questions relating to policy on walkability for the campus (see policy topic below).

"My college is located so far from my faculty and it is impossible for me to walk. The bus service is so poor. It is either buses are too few or they are not following the schedule. So I cannot just rely on my foot. Car is more convenient for me." (Student A) 
Liow Ken Keat, Naziaty Mohd Yaacob \& Nor Rasidah Hashim

Campus Walkability in Malaysian Public Universities: A Case-Study of University of Malaya

Student B cited the lack of covered walkway as their main walkability problem, especially during rainy days.

"During the afternoon, although the weather is hot, I still can use an umbrella because that umbrella still can protect me from the sunlight. But when it is raining, I will still get wet although I am using an umbrella. The sidewalk from my college to my faculty is not covered at all. So, sometimes I will choose to skip the class when it is raining or else I will go in a senior's car." (Student B)

Student C, who considered jogging around the lake, likely had a more convenient way to travel to and from his college than walking. This student also shared their opinion about the National University of Singapore campus where the green landscape ('big trees') provided much needed shade from the sun for the pedestrians there. The comparison with another university campus could be suggestive of poor policy implementation at Universiti Malaya.

"I do not think it 〈walkability> works well on this campus. For exercising purpose, I will jog around the varsity lake but if want to walk from my college to faculty, I will say no. I went to NUS before for some academic program and I think the walkability idea works well there compared to here. I do not know why but I could see most of the students were walking. It may be the landscape, the shaded big trees help to create a more comfortable walking environment." (Student C)

Finally, on the issue of Universiti Malaya's No-Car Policy for First Year students, we found that this policy was not well-accepted by the first year students. The majority $(72 \%)$ of the participants said that they did not adhere to the policy. Only $12 \%$ of the participants agreed that the policy was positive and that they were adhering to it. On the extreme side, nearly $49 \%$ of the participants said that they did not adhere and thought that the policy was negative (Table 3 ).

Table 3: Responses of the respondents towards the University's policy.

\begin{tabular}{lccc}
\hline & $\begin{array}{c}\text { Adhere to } \\
\text { policy }\end{array}$ & $\begin{array}{c}\text { Do not adhere } \\
\text { to policy }\end{array}$ & Total \\
\hline Opinion: policy is positive & $27(12 \%)$ & $51(23 \%)$ & $78(35 \%)$ \\
Opinion: policy is negative & $36(16 \%)$ & $110(49 \%)$ & $146(65 \%)$ \\
\hline Total & $63(28 \%)$ & $161(72 \%)$ & $224(100 \%)$ \\
\hline
\end{tabular}

\section{Ground truthing of street elements}

As mentioned earlier, the direct observation and measurement technique follows the Malaysian Standard of MS 1184:2014 (Malaysian Standards, 2014). Street elements being considered here included curbs, walking surfaces, pathways, lighting, crossings, curb ramps, landscaping, street furniture, and stops (Table 4). 
PLANNING MALAYSIA

Sustainable Urban Development

\section{Pedestrian crossings}

For the pedestrian crossings on campus, we found that there were three types of pedestrian crossings: crosswalk with pedestrian light signal, crosswalk with hatching and raised crosswalk (Figure 2). Crosswalks can be the most dangerous area for pedestrians because of the conflict with vehicular traffic, therefore, wellmarked, mid-block and raised crosswalks would assist pedestrians to cross, while the placement of these crosswalks along with a well-planned traffic system and infrastructure will make for safer, secure and comfortable walking experience, with reduced conflicting points.

Table 4: Summary of findings via direct observation and measurements and suggestions for improvement.

\begin{tabular}{|c|c|}
\hline $\begin{array}{l}\text { Observed and Measured } \\
\text { Findings }\end{array}$ & \\
\hline $\begin{array}{l}\text { Street Elements within Curb-to- } \\
\text { Curb Roadways } \\
\text { - } \quad \text { Pedestrian Crossing } \\
\text { - } \quad \text { Number of Traffic Lanes } \\
\text { - } \quad \text { Width of Traffic Zone } \\
\text { - } \quad \text { Number of Traffic Calming } \\
\quad \text { Devices }\end{array}$ & $\begin{array}{l}\text { With better design such as well-marked crosswalks, mid- } \\
\text { block crosswalks, and raised crosswalks can create safe } \\
\text { walkways on which pedestrian can cross the road with } \\
\text { comfort. } \\
\text { Mid-block crosswalks can improve the walkability by } \\
\text { providing a better access to areas for pedestrian while } \\
\text { limiting the number of pedestrians crossing without a } \\
\text { crosswalk. } \\
\text { Crosswalk to be placed every } 30 \mathrm{~m} \text {. } \\
\text { Median should be designed on the traffic zone, which } \\
\text { exceeds } 2 \text { to } 3 \text { lanes so that the protection and resting point } \\
\text { can be provided for the pedestrians. }\end{array}$ \\
\hline 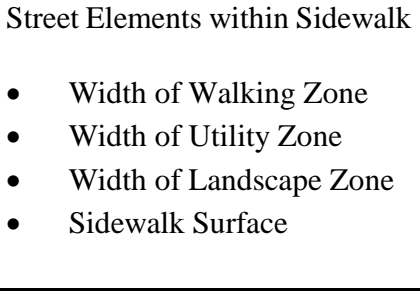 & $\begin{array}{l}\text { Walking zone should be at least } 1.8 \mathrm{~m}-3.0 \mathrm{~m} \text { wide or greater } \\
\text { for higher pedestrian volumes. } \\
\text { Trees planted along the edges of roadways and in medians } \\
\text { would provide a barrier for pedestrians and also help in } \\
\text { slowing down vehicle speeds. } \\
\text { Trees would also help to create a more pleasant environment } \\
\text { for pedestrians and create the image of the roadways as a part } \\
\text { of a place or destination, not just a vehicular route. }\end{array}$ \\
\hline
\end{tabular}


Liow Ken Keat, Naziaty Mohd Yaacob \& Nor Rasidah Hashim

Campus Walkability in Malaysian Public Universities: A Case-Study of University of Malaya

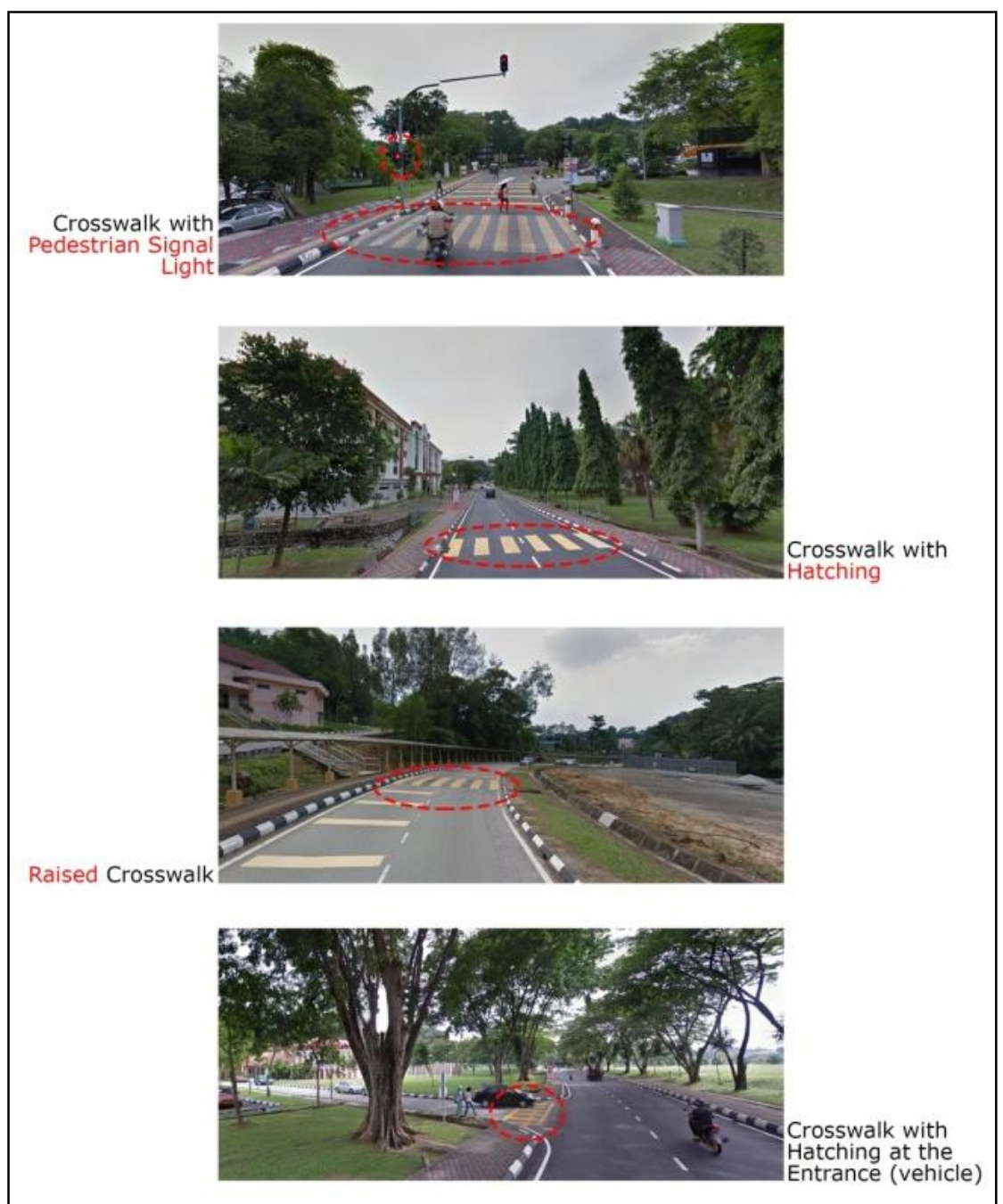

Figure 2: Types of pedestrian crossings.

\section{Traffic zones}

The widths of the traffic zones on campus were found to be in the range of $7 \mathrm{~m}$ to $14 \mathrm{~m}$. The widest traffic zone is at Lingkungan Budi (Figure 3) where the main bus station is located. Referring to Littlefield (2012), the maximum vehicle width permitted is $2.5 \mathrm{~m}$, and the minimum clearance between parallel vehicles is $0.5 \mathrm{~m}$, hence the minimum lane width is $3 \mathrm{~m}$. Our suggestion is to create narrower lanes so as to control vehicle speeds and to shorten crosswalk length. 
PLANNING MALAYSIA

Sustainable Urban Development
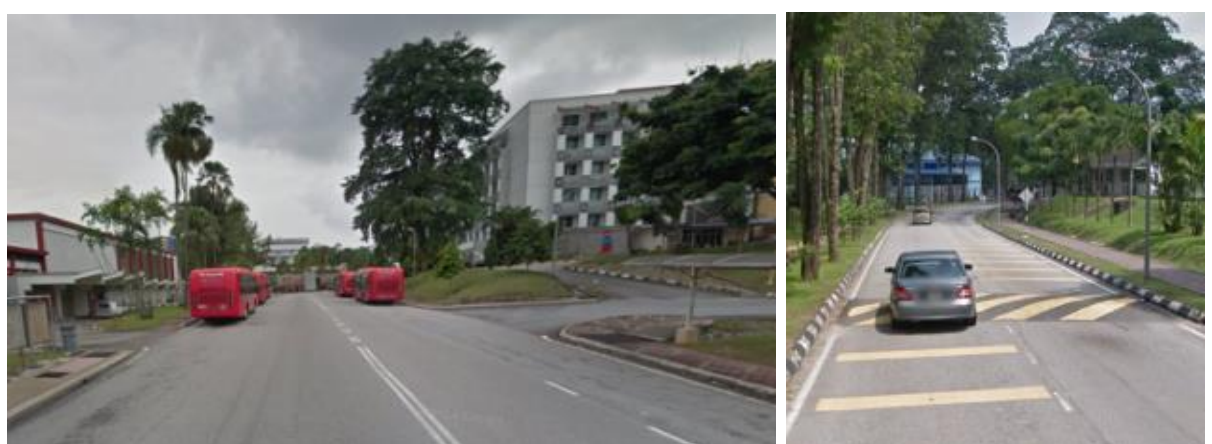

Figure 3: Lingkungan Budi near UM main library (left) and the speed bump (right).

Additionally, traffic calming devices such as speed bumps, raised crosswalk, and textured paving treatments (Figure 3) can help to slow down traffic especially at the pedestrian crossing area. Pedestrian crossings need to be planned and designed together with the vehicular traffic system, where the design of the pathways, curb and road is based on behaviour of both pedestrians and drivers.

\section{Types of pedestrian sidewalks}

There are three types of pedestrian sidewalks that can be found on UM campus. Type A - landscaping zone in between walking zone and traffic zone, Type B buffer zone in between walking zone and traffic zone, and Type $\mathrm{C}$ - walking zone in between landscaping zone and traffic zone (Figure 4). 
Liow Ken Keat, Naziaty Mohd Yaacob \& Nor Rasidah Hashim

Campus Walkability in Malaysian Public Universities: A Case-Study of University of Malaya

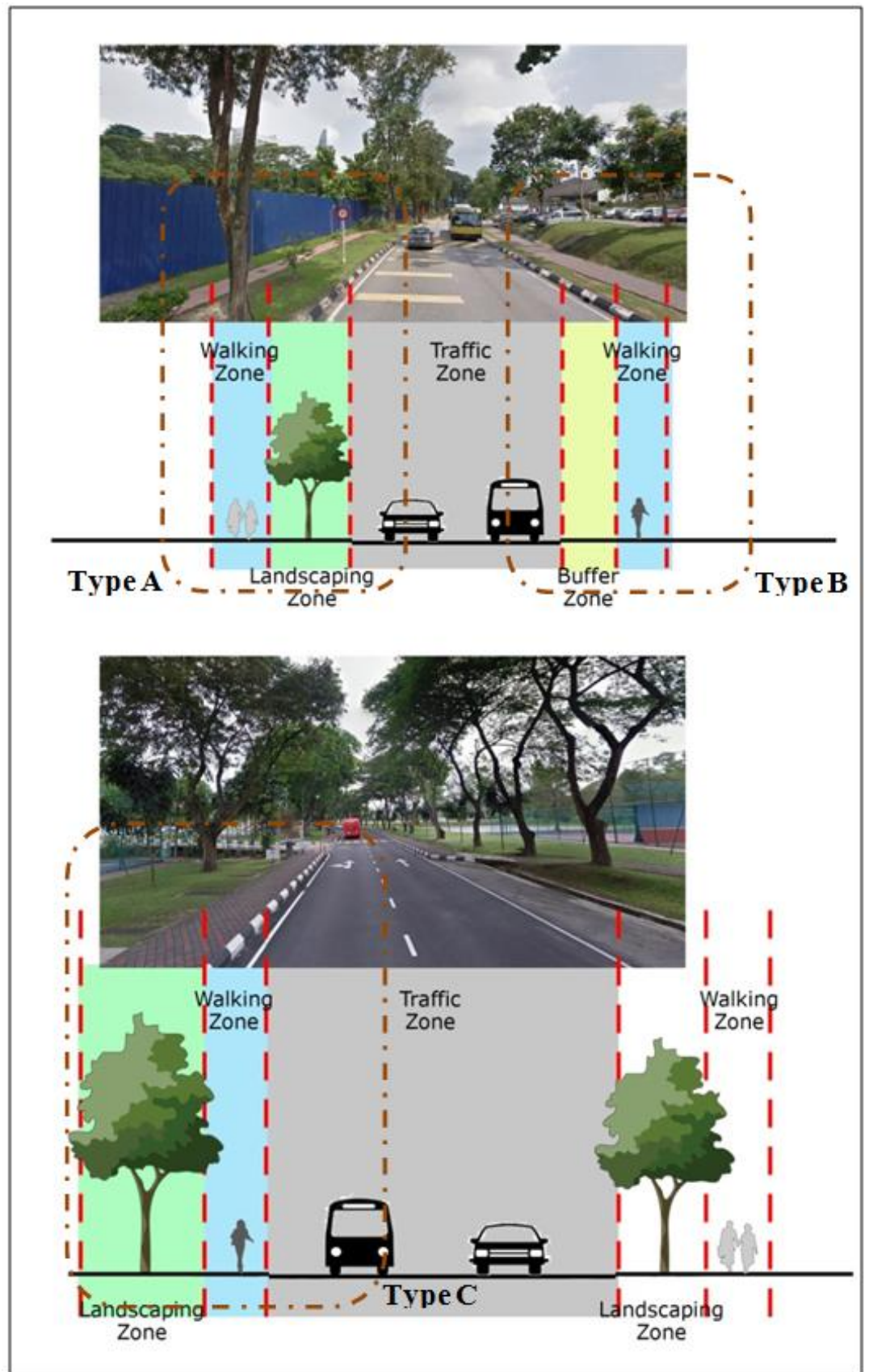

Figure 4: Types of pedestrian sidewalks. 
PLANNING MALAYSIA

Sustainable Urban Development

As pedestrians spend most of their travel in an area called the walking zone (often located on both sides of a road / street), this zone should be free from all obstacles, protruding objects, and any vertical obstructions hazardous to pedestrians, particularly for individuals with vision impairments. The walking zone should be at least $1.8 \mathrm{~m}-3.0 \mathrm{~m}$ wide or greater to meet the desired level of service in areas with higher pedestrian volumes, so as to allow pedestrians to walk side by side or for pedestrians going in the opposite direction to pass each other (Boodlal, 2003). Moreover, the walking zone should not be less than $1.2 \mathrm{~m}$, which is the minimum width required for people with disabilities (e.g. those using a guide dog, crutches, and walkers), and wheelchair users need about $1.5 \mathrm{~m}$ to turn around and $1.8 \mathrm{~m}$ to pass other wheelchairs (Boodlal, 2003). The width of the walking zone found on the campus is in the range of $1.5 \mathrm{~m}$ to $3.6 \mathrm{~m}$ but the average width is $1.6 \mathrm{~m}$.

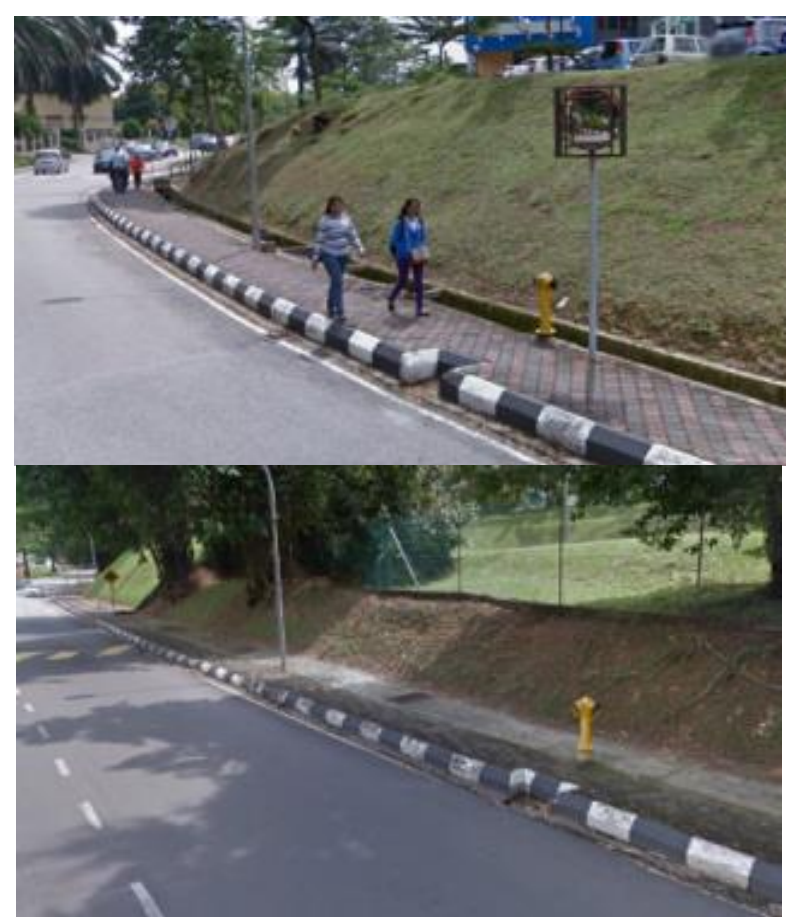

Figure 5: The sidewalk in front of Faculty of Built Environment (above) and the sidewalk outside of Second Residential College (below).

According to Boodlal (2003), a utility zone provides a buffer from the traffic zone and allows for the consolidation of elements like utilities (poles, hydrants, telephone kiosks, etc.) and street furniture (benches, signs, etc.), and although there is no specific or minimum width of utility zone mentioned, $1.2 \mathrm{~m}$ is preferred. During our survey, we found that in certain areas on campus, the 
Liow Ken Keat, Naziaty Mohd Yaacob \& Nor Rasidah Hashim

Campus Walkability in Malaysian Public Universities: A Case-Study of University of Malaya

utility zone and the walking zone were combined as one and this had created the obstruction for the pedestrian travel (Figure 5).

A pedestrian walking experience can also be improved by the presence of shade and visual aesthetics as provided by vegetation (trees and shrubs), which can also act as auditory buffer between pedestrians and the traffic (Figure 6). However, vegetation causes sidewalk cracks and changes in level (i.e. the vertical rises between adjacent surfaces), which could pose difficulty for persons with disability to lift their feet or crutches. Moreover, it is difficult for wheelchair users to roll over large changes in elevation. Low hanging branches also pose a safety hazard, especially for pedestrians with vision impairments who may not detect them and other pedestrians with mobility impairments may have difficulty bending under them. Therefore, careful selections of tree type, their placement and maintenance will provide a comfortable and safe walking environment.

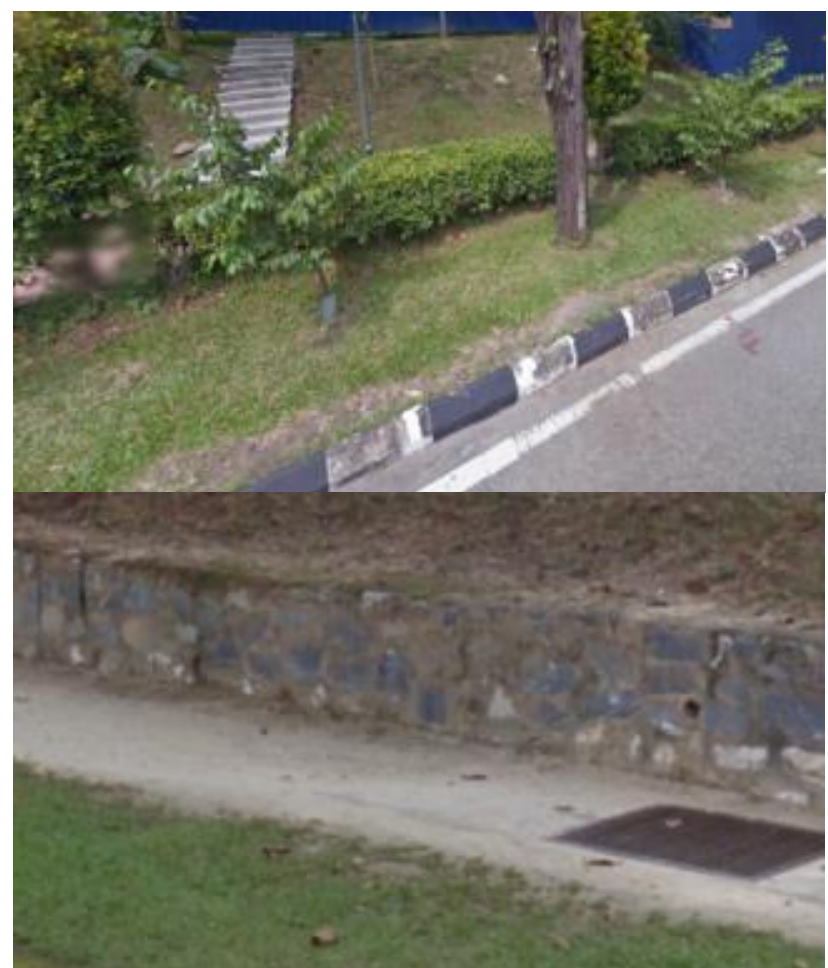

Figure 6: Landscape zone (in front of walking zone) near the Center of Foundation Studies in Science (above) and the concrete sidewalk with manhole (below).

At UM, a common feature of sidewalks built above drainage is the presence of manholes for maintenance purpose (Figure 6). These manholes are a problem unto themselves if and when pedestrians dropped their keys and hand 
PLANNING MALAYSIA

Sustainable Urban Development

phones through the grating into the manholes, whilst manholes that are not properly covered / maintained pose hazards to especially pedestrians with walking aids or in wheelchairs. It is recommended that sidewalk pavements (made using concrete, tarmac etc.) need to be slip-resistant and visually contrasting. Surfaces that are not slip resistant are especially difficult for people who use wheelchairs or walking aids to travel across. For example, crutch users rely on being able to securely plant their crutch tip to travel effectively on the sidewalk. Besides that, surfaces that are not visually contrasting (all one colour and texture) can make it difficult for pedestrians with vision disabilities to distinguish the difference between a change in colour and pattern on the sidewalk.

\section{CONCLUSION}

It has long been known to the built environment professionals (architects, planners, surveyors etc.) that people's behaviours can be shaped by how the built environment is designed, planned and constructed. In the case of walking in UM, how the campus is designed, planned and then constructed over time (e.g. negotiating the topographic features, catering to increasing population size and needs as well as the academic and co-curricular activities) has either encouraged or discouraged people's (students, staff and visitors) from walking around the campus or in certain areas on campus. On UM campus, priority should be given to the pedestrians, especially if the No-Car Policy is to be successful. All road users should be made aware of such policy and the whole system should accommodate the policy. Furthermore, the campus management team should reconsider the issue of 'walking distance' between the students' hostels and faculties as some students perceive such distances are deterring them from walking to and from these places. 
Liow Ken Keat, Naziaty Mohd Yaacob \& Nor Rasidah Hashim

Campus Walkability in Malaysian Public Universities: A Case-Study of University of Malaya

\section{REFERENCES}

Angelidis. C., Candlish, J., Haynes, J., Holder, A., Smith, O. \& Ashley, H. (2014), Studley Campus Walkability Assessment. Odalhousie University.

Boodlal, L. (2003), Accessible Sidewalks and Street Crossings - an informational guide. US Department of Transportation, Federal Highway Administration, Washington, DC

Banning J. H. (1993). The pedestrian's visual experience on campus: informal learning of cultural messages. The Campus Ecologist, 11(1), 1-4.

Emery, J. \& Crump, C. (2003). The WABSA Project: Assessing and Improving Your Community's Walkability and Bikeability. University of North Carolina at Chapel Hill.

Handy, S. (2005). Critical Assessment of the Literature on the Relationships among Transportation, Land Use, and Physical Activity. Transportation Research Board and the Institute of Medicine Committee on Physical Activity, Health, Transportation, and Land Use. Resource Paper for TRB 79 Special Report 282.

Lewis, R. K. (2004). Bricks, mortar, and vision: a guide for campus planning. The Chronicle of Higher Education, 50(29), B20-B22.

Littlefield, D. (2012). Metric Handbook Planning and Design Data. London: Routledge.

Makki, S., Surat, M., Che-Ani, A-I., Farkisch, H. \& Mokhtarian, H.R. (2012). The importance of design characteristics in walking from student's perspective: a case study in Universiti Kebangsaan Malaysia. Journal of Building Performance, 3(1), 42-49.

Malaysian Standards (2014). MS 1184:2014; Universal Design and Accessibility in the Built Environment-Code of Practice for the Public.

Mohd Zulhanif, A.R., Nur Akmal,G.A., Muhammad Farihan Irfan, M.N., Ismar M.S.U. \& Adi Irfan, C-A. (2011). Toward a sustainable campus: comparison of the physical development planning of research university campuses in Malaysia. Journal of Sustainable Development, 4(4), 210-221.

Park, S. (2008). Defining, Measuring, and Evaluating Path Walkability, and Testing Its Impacts on Transit Users' Mode Choice and Walking Distance to the Station. PhD Dissertation, University of California Transportation Center, Berkeley.

Registration Admissions and Records of Universiti Malaya (2014). unpublished.

Rugayah, H., Shireen, H., Sabariah, M. \& Farihah, H. (2013). Assessment of campus bus service efficacy: an application towards green environment, Procedia - Social and Behavioral Sciences, 105, 294 - 303.

Strange, C. C. \& Banning, J. H. (2001). Educating by Design: Creating Campus Learning Environment That Work. San Francisco: Jossey-Bass. 